\title{
ISLAMIC MONEY MARKET: AN INSTRUMENT FOR MANAGING LIQUIDITY RISK IN ISLAMIC BANKS
}

\author{
Sekoni Abiola Muttalib*
}

\begin{abstract}
The general consensus of financial experts is that liquidity is the lifeblood of any organisation, which is inclusive of Islamic banks. Hence, effective liquidity management is essential for the efficiency of banking institutions and the economy as a whole. The major provider of liquidity is the short-term money market instruments. Islamic financial institutions just like their conventional counterparts use short-term mobilised deposit funds to finance long-term loans and projects which expose them to asset liability mismatches and thus, are vulnerable to liquidity problems. Addressing the potential liquidity risk due to the cash-flow mismatches requires an efficient and vibrant Islamic money market as it is an essential and integral part of Islamic financial system. It therefore raises the need for developing an Islamic money market where Shari'ah-compliant financial instruments are to be traded and operated based on Shari'ah principles. Although it is considered the surest approach to sound liquidity risk management in Islamic banks, the dilemma that Islamic money markets are facing now is acute shortage of Shari'ah-compliant financial instruments and the controversies surrounding the few available instruments. A successful liquidity risk management therefore requires ensuring well functioning Islamic money markets with some if not all controversies/addressed through embarking on development of new products or promoting innovation in order to enable Islamic banks to compete effectively with their conventional counterparts. Hence, this study attempts to present a better understanding of various Islamic money market instruments, their roles in managing liquidity and their relationship with liquidity risk management.
\end{abstract}

Keywords: liquidity risk, liquidity management, Shari'ah-compliance, innovation, new product development and Islamic inter-bank money market.

\section{Introduction}

It has been highlighted in many studies that Islamic banking institutions differ from their counterpart conventional banking institutions in so many ways. Although exhibiting many significant differences, Islamic financial institutions, like their conventional counterparts, are exposed to the common short-term liquidity risk faced by banking institutions operating within the system of fractional reserve banking. This could be traced to the fact that Islamic banks are also engaged in transactions involving both long-term assets and short-term liability portfolios, thereby creating cash-flow mismatches. Aggravating this situation is the nonShari'ah compliance of the available short-term funds in the money markets. Inability of Islamic banks to source for short-term funds from the conventional 
money markets calls for a development of a separate Islamic money market which will strictly comply with Shari'ah laws and principles.

The money market is simply defined as a venue where transactions involving medium and short-term instruments are carried out with transaction tenure ranging from overnight to 12 months. The commonest tenure is less than or exactly three months. In fact it is a financial market in which wholesale short-term funds are transacted. An increase in the number of money market instruments available in the Islamic money market will increase Islamic bank's investment opportunities and exposure to wide range of assets diversification.

Critical to the well functioning of the Islamic banking system is the Islamic money market because of the vital functions it can perform in the financial system. It provides the Islamic financial institutions with the facility for raising funds and adjusting portfolios over a short-term. It is used by Islamic banks to assuage their liquidity problems, specifically for handling Assets and Liabilities mismatches (ALM). The central bank in controlling the level of liquidity in the system employs the money market for transmission of its monetary policies. Governments and business organisations also find the money market as a useful venue for short-term investments by usually raising short-term funds through securities issuance. It is indeed a venue where banks, business organisations and government can buy and sell money instruments and also invest their surplus funds. However, financial instruments and inter-bank investment allow surplus banks to channel funds to deficit banks, thereby maintaining the funding and liquidity mechanism necessary to promote the stability of the banking system.

Presently, Islamic banks rely mostly on usage of short-term deposits on variable rates to finance medium and long-term projects. The situation leads to Islamic banks either to maintain high liquid ratios or to avoid long-term financing which can affect the overall profitability. Therefore, special attention needs to be directed towards development of Islamic money market instruments to meet Islamic banks' liquidity requirements in order to match the current market financing rates on a constant basis. Current available Islamic financial instruments are either long-term or fixed in nature which creates funding- mismatches problems.

It is noteworthy that with the exception of Malaysia, other countries that licensed Islamic banking operation are yet to have sufficiently developed Islamic money markets. The markets lack sufficient availability of Shari'ah compliant financial instruments. This inhibits and negatively impacted crossborder flows of liquidity among Islamic banks. Resolving these problems will require new product developments and innovations in Islamic money markets in each jurisdiction to facilitate Islamic banks' management of their liquidity gaps efficiently as the conventional banks. Aside this section, there are four other sections in this paper. Section two provides insight into money market. Section 
three discusses the Islamic money market. Section four relates Islamic money market instruments and the liquidity risk management while the last section concludes the paper.

\section{Overview of the Money Market}

The paramount importance of financial markets is to transfer funds from the surplus units (lenders) to the deficit units of the economy (borrowers). The common practice in the financial markets is to distinguish capital market from the money market. While the capital market deals with long-term financial instruments, money market generally refers to short-term lending and borrowing for period of one year or less (Timothy \& Robert, 1998). In other words, the basic difference between capital markets and money markets is in terms of the liquidity of the instruments or securities. Normally, the instruments in the capital markets are less liquid compared to the instruments in the money market (Billah, n.d). It implies that the money market securities are short-term in nature with original maturity less than one year, have low risks, and are very liquid.

Money market in finance is recognised globally as an integral part of financial markets for short-term borrowing and lending. It is a source of short-term liquid funding for global financial markets. The money market is the place where shortterm financial instruments or obligations like commercial papers, treasury bills, and bankers' acceptances can be bought and sold. The main objective of the money market is to meet short-term liquidity requirements of financial institutions, banks included. The market facilitates banks with deficit in cash to borrow from the banks having surplus money. Islamic money market performs a similar function of meeting the Islamic banks' short-term liquidity needs. But instead of interest, it allows Islamic banks to share surplus capital on profit-sharing basis.

Basically, money market is composed of financial institutions, governments, and dealers in money or credit who intend to either lend or borrow from the market. The activities of the participants in the market typically involve shortterm borrowing and lending which may start from overnight and up to thirteen months. The name as observed by Billah (n.d) does not signify that fiat money is the instrument involved in this market, but rather, the name came about because the securities involved in this market are highly liquid and are thereby so close to being money. Robert and Lotte (2009) described money market as a market for deposits and short-term debt securities-such as bankers' acceptances, commercial paper, repurchase agreements (repos), negotiable certificates of deposit, and Treasury bills - which have maturity of one or less than one year and in most cases 30 days or less.

Money market is a critical component of the larger financial market system, and characteristically, their instruments have lower risks and high liquidation 
features, as the maturity horizon for most of these instruments is less than 120 days, and as a result usually generate low returns. The transactions in the money markets mostly involve large amounts, and therefore, any interference whatsoever, from individual investors, is not allowed. Hence, money market is a dealer market where the participants buy and sell securities on their own account and at their own risk. Moreover, there is no specific place (building) earmarked for money market transactions, instead they are conducted through phone calls and electronic systems, and money market instruments usually have active secondary markets.

Money market is critical to the well functioning and stability of the banking system. In fact efficiency of banks greatly depends on the viability of money market, as banks rely on money market in managing their liquidity. Although, there is numerous usefulness of the money market to banks, the most important is liquidity management. Banks' dependence and dominance on money market is so high that it is popularly known as the Inter-bank Money Market (IMM). Due to the linkages among the money market, the capital market and the banking system, it is being used by central banks as a means to conduct monetary operations (Obiyatullah, 2007). It therefore follows that money market is always the first to feel the impact of any monetary policy change. Technically, to a central bank in its monetary policy implementation, the first responses are always from the short interest rate or yield derived from transactions in money market. Because of the linkage, reactions of the money market automatically trigger adjustments in the bond-cum-equity market and banking system. Hence, an efficient money market properly transmits monetary policy initiatives to the other components of the financial system.

\section{Participants in the Money Market}

Lenders and borrowers are the traditional participants in the money market, as the core business of the money market involves parties borrowing and lending among themselves using commercial paper, repurchase agreements and other similar instruments. The parties involved are usually the government, banks, businesses, investments companies (e.g. brokerage firms), finance companies (Commercial leasing companies), insurance companies (property or casualty insurance companies) or pension funds providers. Governments, federal, state or local can raise a huge sum of funds in the money markets by issuing/selling short-term instruments known as Treasury bills to fund public debt. Occasionally, state and local governments do issue municipal paper. Of all money markets instruments, treasury bills have the largest volume outstanding and the most active secondary market. 
In the case of businesses, funds are usually raised in the money markets by issuing commercial paper for local transactions, while funds are raised through bankers' acceptance for business that involves international trade. The acceptance may be held by the bank or sold in the secondary market. Typically, finance companies raise their funds via issuance of substantial amounts of assetbacked commercial paper (CP), secured by the pledge of eligible assets into a commercial paper conduit such as credit card receivables, mortgage backed securities, automobile loans and other similar financial assets.

At the centre of the money market's trading activities are the brokers and the dealers who are responsible for marketing new issues of money market instruments as well as provision of secondary markets. They also play intermediary roles between market participants by linking the borrowers and lenders in the markets. However, banks' participation in the money market involves raising (borrowing) funds to enable them to support their loan portfolios and to meet the statutory reserve requirements. They act as dealers in the markets for over-the-counter (OTC) interest rate derivatives, and provide commitments that ensure timely payment to the investors in money market securities (KFH, 2012).

\section{The Islamic Money Market}

The exponential growth of Islamic financial system shifted attention to the urgent need for the development of a vibrant and efficient Islamic money market which is an essential element for both the effective supervision and risk management of Islamic financial institutions, not to mention the development of well-functioning capital markets (IFSB, 2008). Furthermore, Islamic money market coupled with supportive infrastructures creates stability in financial system and also provides the basis for broad-based market development. Mark (2011) referred to Islamic money markets as the markets in which creditworthy, Shari'ah-compliant instruments with maturities of not more than one year are issued or traded among the financial institutions. Therefore, Islamic money market plays a pivotal role in ensuring well and adequate functioning of the Islamic finance industry by:

- Providing the Islamic financial institutions with the facility for funding and adjusting portfolio over the short-term.

- Serving as a channel for the transmission of monetary policy.

In other words, healthy operation of Islamic banking system is contingent on the existence of a viable and liquid money market with vibrancy that provides Islamic financial institutions the ability to effectively manage their portfolios in the short-term through a dependable funding facility (KFH, 2012).

Although there are Islamic money markets in countries like Bahrain, Indonesia, UAE and Brunei, the Malaysian money market is believed to stand 
out as one of the main and leading money markets in terms of variety and range of offered products. It is worthy to note that Islamic money markets instruments, unlike its conventional counterpart which are similar across jurisdiction, are varied in different countries. Mark (2011) observed that the variance is due to differences in Shari'ah interpretation in each jurisdiction. Basically, instruments that are allowed in Islamic money markets should adhere strictly to the Shari'ah principles of Islamic finance.

However, there are some similarities between Islamic money market and the conventional counterpart. Islamic money market, sharing the structure of conventional counterpart has three main components namely: the financial instrument offering Islamic products, the Islamic inter-bank market for deposits, and the cheque clearing and settlement system. This is depicted in the diagram below:

\section{Figure 1 Overall Structure of IIMM}

\begin{tabular}{|l|l|}
\hline $\begin{array}{l}\text { Islamic } \\
\text { Interbank } \\
\text { Money Market }\end{array}$ & Islamic Money Market Instruments \\
${ } }$ & Islamic Interbank Deposits \\
\hline Islamic Cheque Clearing System \\
\hline
\end{tabular}

Source: Obiyathullah, 2007

\section{The Islamic Inter-bank Money Market (IIMM)}

The interbank money market is a very important component of this market, perhaps the most important based on arguments of some studies. Islamic banks, commercial and merchant banks as well as discount houses are the allowed participants in the Islamic Inter-bank Money Market. The scope of activities of IIMM includes the following:

- Purchase and sale of Islamic financial instruments among market participants,

- Inter-bank investment activities through the Mudarabah Inter-bank Investment (MII) scheme,

- Cheque clearing and settlement system through an Islamic inter-bank Cheque Clearing System (IICCS).

However, the second activity, i.e. Mudarabah Inter-bank Investment (MII) is considered the nucleus of the Islamic inter-bank market. It is the mechanism through which banks exchange funds among themselves. Banks with surplus funds are able to invest in those with deficits in liquidity using the mode of 
financing based on Murabahah with a negotiated profit-sharing ratio (PSR). The term of investment varies from overnight to 12 months depending on the mode of financing involved. Implementation of IIMM has been a success without a hitch, except only one drawback, that is lack of sufficient amount of Shari'ah compliant financial instruments. Hence, to sustain the smooth functioning and at the same time improve on the vibrancy of IIMM concerted efforts should be made towards innovation and development of many new varieties of Islamic financial products that can be easily traded in the IIMM.

With respect to Mudarabah Inter-bank Investment, Obiyathullah, (2007) emphasised that the pricing or cost of funds for a given amount and term would depend on two unknowns:

1. The profit-sharing ratio (PSR) which is to be negotiated; and

2. The gross profit rates before distribution of the receiving bank on one-year investments that it will declare. The declaration is supposed to be made by the receiving bank at the maturity date of the MII. In other words once the profit-sharing ratio is agreed upon, there is only one unknown, namely the profit rate that would be declared by the receiving bank. However, part of this uncertainty is reduced in the sense that the investing bank knows that it will be the higher of the following:

(a) The prevailing rate on GIC (Government Investment Certificate) of the same term $+0.5 \%$ (annualised), if the declared profit rate is lower than this, or

(b) The declared profit rate adjusted for PSR, if it is higher than the Government Investment Certificate (GIC) $+0.5 \%$ annualised.

The formula used in determining the (price) profit amount due to the provider of funds (investing bank) given by Obiyathullah is as follow;

$$
\mathrm{X}=\operatorname{Pr} \mathrm{t}(K) / 36500
$$

Where;

$\mathrm{X}=$ Ringgit (RM) amount to be paid to investing bank

$\mathrm{P}=$ Face value / principal amount of investment

$\mathrm{t}=$ Term in days of investment

$\mathrm{r}=$ Gross profit rate before distribution declared by receiving bank on one year investments

$\mathrm{K}=$ Profit sharing ratio

\section{Islamic Inter-bank Cheque Clearing System}

Islamic Inter-bank Cheque Clearing System refers to the system through which clearance of the cheque deposits and withdrawals between the Islamic banks 
are carried out. In conducting this function, central banks assumed the role of intermediaries in setting the net between the Islamic banks. Ensuring proper functioning and Shari'ah-compliance of Islamic Money Market requires establishment of a separate cheque clearing system for Islamic financial sector. To address this need, central bank is required to take two basic initiatives which are:

- All Islamic banks should be directed to maintain Al-Wadia (safe-keeping) based account with the central bank; and

- Central bank should require/sought empowerment from all Islamic banks to reconcile and stabilise the differing funding position, between deficit and surplus banks during the midnight automatic cheque clearing process.

However, Bank Negara Malaysia (BNM) is empowered by Islamic banks on the basis of Al-Wakalah concept (Obiyathullah, 2007). Al-Wakalah, according to Ijlal (2009), is currently gaining momentum and patronage due its advantages where no commodity and brokerage are required and is very competitive. The empowerment thus, allows Central Bank to place surplus funds of an Islamic bank with other deficit-ridden Islamic banks. However, in the case of Mudarabah Interbank Investment (MII), placement of funds of the banks with surplus to the deficit banks is done based on Mudarabah concept with profit-sharing ratios usually fixed at 70:30.

\section{Islamic Money Market Instruments}

The name money market is a term that collectively refers to markets where short-term high quality and liquid credit instruments are traded. Fitting into this category are securities with maturities that fall within one year and are generally issued in the primary markets through telecommunication network or electronic system by banks, governments, financial companies and corporations to obtain short-term funds. The purchased securities in the primary market are generally sold in the secondary market to other financial institutions and government agencies that are in possession of surplus funds available for a short-term period for liquidity enhancement. As a matter of fact most financial institutions and companies usually maintain some holding of money market securities.

There are two different ways through which the securities can enhance the liquidity of the participating institutions. Firstly, the institution that issues new securities had succeeded in creating a short-term liability in order to boost their cash balance, as newly issued securities generate cash. Secondly, institutions that initially purchased money market securities will generate cash upon selling or liquidating the securities, in this case, one type of asset (the security) is replaced by another (cash). As usual at initial stage, in order to conform to Shari'ah principles, Islamic banking sector replicated some conventional money market 
instruments, particularly the most popular three which are: (i) Treasury bill; (ii) Call money; and (iii) Certificate of deposits.

(i) Treasury Bills

These are short-term debt instruments that are issued in 3, 4, and 12 month maturities for the purpose of financing. They pay a specified amount at maturity and have no interest payments, but by selling at a discount that is at a price lower than the set amount paid at maturity they invariably and effectively pay interest. Treasury bills symbolise short-term obligations usually issued by a government for the monetary policy purpose by way of controlling the amount of money in circulation. Due to their easy marketability, safety and short-term maturity which is typically three (3) months, they represent one of the most liquid and popular money market instruments. There are numerous reasons responsible for their special attraction as investment instruments. These reasons include the following:

- They have no default risk per se;

- They are highly liquid;

- They benefit from a well-developed secondary market;

- They are used to mop up excess cash from the banking sector;

- They help the government to borrow from banks to meet its budgetary shortfalls;

- They are used in many countries as instruments to carry out monetary policy;

- They are used by central banks whenever an economy is too liquid with surplus funds to mop up the excess liquidity; and

- They are used to pump funds back into the economy whenever there is shortage of funds in the economy through central banks buying back the treasury bills.

(ii) Call Money

It is a money market's key component in which participation of banks aid them on daily basis to overcome and smooth the temporary mismatches in their assets and liabilities. Most of the call money markets do not have either brokerage house or intermediary, hence, transactions are usually based on bilateral negotiations. Effective lending and borrowing is encouraged and allowed between banks and other financial institutions by call money market. But it is advisable for lending institutions/banks to always exercise caution in the selection of borrowing bank or financial institutions because call money loans are practically unsecured.

Ordinarily, the supply of and demand for overnight funds have greater influence on call money market. So also the central bank through open market operation can directly adjust the amount of funds available in the banking system in order to influence the call money rate and several other short-term interest rates (Hakim, 
2007). However, it should be noted that at any point in time call money rate is always slightly higher than treasury bills' rate due to the former's no default risk feature. The call money market is a subset of the inter-bank market where negotiation is often brokered over telecommunication system between two banks.

Liquidity in the call market operating within a smaller market is often sourced from foreign banks because cost of fund for foreign banks are often low compared to that of local banks (Hakim, 2007).

\section{(iii) Certificates of Deposit}

Negotiable certificate of deposit is a large denomination certificate of deposit (CD) and a financial savings instrument issued by financial institution like bank which usually requires a high minimum deposit. Banks, in order to raise funds usually issue Negotiable certificate of deposits (CDs) which is the large denomination negotiable liabilities often issued at a discount to businesses and government agencies with a fixed maturity and interest rate. Owing to the fact that certificate of deposits are usually issued in large amount, the issuance is primarily done by the largest banks. Another striking feature of certificate of deposits (CDs) is having an active liquid secondary market where the certificates can be sold. Therefore, through the sales of $\mathrm{CD}$, the holder of the instrument can effectively redeem the deposit before it matures without losing funds to the bank. The CDs marketability attribute makes them attractive to temporary holders of substantial funds and allows banks to tap money markets for quick access to borrowed funds (Hakim, 2007).

When a bank issues a certificate of deposit, it guarantees the holder to be paid back deposit plus interest. Like normal certificate of deposits, negotiable certificate of deposits last for a predetermined duration and funds cannot be withdrawn from the deposit account until the agreed date. The operation of CDs is typically on a short-time frame. Usually demand and the maturity of the certificates are after one year or less. This is because investors usually demand for CDs of short-term, discounted investment which over an agreed time will provide a fixed interest rate return.

Ordinarily, a negotiable certificate of deposit which often comes in bearer form is traded at a discount to the face value to be repaid on maturity. However, some negotiable CDs may come with longer terms and offer higher interest rates. It is important to note that negotiable certificate of deposit cannot be redeemed before its maturity.

Nevertheless, Sundararajan and Errico (2002) observed that partly due to Islamic banks' increasing needs to address and cope with their liquidity issues, they had embarked on expansion of the scope and scale of their transactional activities through which traditional investment and financing instruments are 
restructured so as to develop Islamic money market instruments that would be in conformity with Shari'ah principles. This method was employed to Islamise common traditional money market instruments via removal of the interestbearing features and replicating them with Shari'ah compatible ones such as profit rate and mark-up features (Obiyathullah, 2007). As a result, instead of Banker's Acceptance we now have Islamic Bankers' Acceptances, Negotiable Islamic Instrument of Deposit (NIIDs), replicated Negotiable Instruments of Deposit (NIDs). Malaysian Treasury Bills were replicated and became Malaysian Islamic Treasury Bills etc.

In addition to the replication of traditional instruments, some conventional transaction processes like the well-known Repurchase Agreement (REPO) were copied from the traditional money markets. The Islamic version of REPO is known as the Sell and Buy Back Agreement (SBBA). The SBBA allows the parties to initial sale at a negotiable price to enter into a separate agreement to reverse the trade at a newly negotiable price. SBBA is commonly used in Malaysia.

Some of the countries where Islamic banking is being practised are making frantic efforts to develop their individual Islamic money market with different instruments. The major problem is acceptance of these instruments in all jurisdictions. Instrument accepted as Shari'ah compliant in one country may be rejected in another. However, it is noteworthy that these instruments had succeeded in providing Islamic alternatives to the interest-bearing traditional instrument. Generally, according to Hakim (2007) the most recent Islamic money market securities include the following:

Tradable Islamic financial assets such as:

- Mudarabah certificates

- Musharakah certificates

- Musharakah Term Finance certificates

- Murabahah and Istisna certificates

- Salam certificates

Sukuk structures which include:

- Ijarah Sukuk

- Hybrid Sukuk

- Variable Rate Sukuk

- Zero-coupon Non-tradable Sukuk

Mudarabah certificates: Mudarabah is a mode of project financing based on partnership principle. The certificates thus, represent permanent ownership in a project, business or company. However, the holder of the certificate is by rules neither allowed to take part in the management nor entitled to exercise control in the management or voting rights. 
Musharakah certificates: Just like Mudarabah, it is also a mode of financing that is based on the principle of partnership. The certificates represent the same thing as in Mudarabah certificates. The only difference is that the holders are allowed to participate in the management's daily running and affairs of the project, business or company. Thus the holder of a certificate is entitled to the management control and voting rights.

Musharakah Term Finance certificates: These certificates entitled the bearer to a temporary ownership of a project, business or company which, may include or exclude management control and/or voting rights. Two types of these certificates based on Ijarah concepts are used for durable assets. Though they are sometimes used as money market instruments but, they are typically considered as capital market instruments.

Musharakah and Istisna certificates: These are debt securities emanating from standard Istisna or Musharahah contract. With these certificates, there is no breaking up of the periodic repayment of debt between principal and coupons, and the total debt or any portion. Therefore, Shari'ah compatibility of these certificates is in doubt due to Shari'ah's ruling which prohibits debt trading. In a nutshell, the certificates share similarity with zero coupon securities. Consequently, these certificates are less attractive due to lack of secondary market. Apparently, opinions differ and conflict on the tradability restriction of these certificates. Aside this, the instruments are very popular and being traded in the domestic bond markets.

Salam certificates: These certificates stand for securities that are derived from Salam contracts in which prepayment is allowed for the future delivery of a commodity. The funds prepaid can represent debt certificates for a commodity. However, the certificates, for the same reasons that applied to Murabahah and Istisna certificates are rendered non-tradable.

Prior to the discussion on Sukuk structures it is important to make some clarifications on the term "Sukuk". Such clarifications include the following:

- Sukuks are Shariah compliant equivalent of traditional securities backed by tangible assets which cannot be backed with asset exclusively made up of debt.

- Sukuk structures are characterised with different terms.

- Sukuks' classification into either money or capital market is contingent on a specific structure's term.

- Sukuks are structured financial instruments.

- Sukuks are not IOUs or debt instruments like conventional bonds.

Ijarah Sukuk: This is the earliest and predominant Sukuk that has been issued to date. The investors' familiarity with the Ijarah sukuk (i.e. its sale and leaseback structure is easy to understand even by a layman in Islamic financing) accounts 
for its prevalence. Sukuk al-ijarah certificates are usually backed by lease agreements of buildings, lands or equipments. The returns on the certificates which are determined by the underlying lease payments may be fixed or variable. The terms of the certificates and the underlying leases are expected to coincide, though there is nothing that forbids sukuk having shorter-term.

Musharakah and Mudarabah Sukuks: These sukuks were developed as a result of drawbacks of sukuk al-ijarah. The essence was to overcome the identified disadvantages of Ijarah sukuk which, according to Rahail (2011) include:

- The Sukuk issue amount cannot be justified if the value of the assets (i.e. the subject of the sale and leaseback structure) does not approximate the issue amount.

- Sukuk structural inflexibility to accommodate commercial points such as periodic redemptions and the obligor's commercial need to dispose of or deal with the assets immediately if they are on lease.

The proceeds of these Sukuk instruments are notably used for financing construction projects, and avoid complications which Ijarah sukuk faces in generating acceptable periodic returns during the construction phase. Also, they offer investors an option for settlement in commodities rather than cash (Rahail, 2011).

Hybrid sukuk: This sukuk structure is made up of revenues generated from combination of different structures. In a situation where the underlying revenues are mixed and are not solely dependent on revenues from leases, but rather include Istisna or Murabahah receivables, then the Sukuk certificates are referred to as hybrids provided that the lease-based proportion of the assets exceeds 50 per cent.

Sometimes, the Sukuk certificates are collateralised by issuers who may be willing to step in by pledging some assets more than the underlying leases. The advantage of this action is enhancement of the credit quality of the certificates. These certificates are characterised by a more stable cash flow to the certificate holders, as the holders have the advantage of depending on both the dividend payout from the leases and the direct profitability of issuer.

Zero-coupon Non-tradable Sukuk: These certificates share similarities with Murabahah and Istisna certificates in the sense that the backing assets are usually not in existence or not completed at the time of the Sukuk issuance. Therefore, the restriction imposed by the Shari'ah on secondary market tradability affects these certificates (Hakim, 2007).

In addition to the instruments discussed above, this paper endeavours to highlight and give special attention to the most common instruments being issued in the Islamic money markets, specifically the Malaysian money markets. 
Availability of varieties of short-term money market instruments enormously contributes to the market's vibrancy which enables it to achieve the aims and objectives of its establishment, though not without some shortcomings and hiccups here and there.

The essence of having Islamic money market is to ensure healthy operations and efficiency of Islamic banking system, which if liquid, will through funding facilities enable banking institutions to adjust their portfolios in the shortterm. Efficient issuing and trading infrastructure of the money market ensures operational efficiency and financial stability. To accomplish this, Islamic interbank money market was established and structured as a short-term financial intermediary for the provision of a ready source of short-term investment outlets based on Shari'ah principles. The common instruments being traded in the IIMM include the following:

\section{Al-Mudarabah Inter-bank Investment (MII)}

The Mudarabah inter-bank investments is a type of financial instrument through which surplus and deficit Islamic banks can lend and borrow funds among themselves on a Mudarabah profit-sharing basis. The investment period usually range from overnight to twelve (12) months. As a matter of fact, in the interbank market much of the money is lent overnight, that is on a day-to-day basis, or at weekends for three days. However, quite a lot of money can also be borrowed for very short periods of time. Banks may borrow for seven days, fifteen days, or for almost any amount of time up to twelve months (Obiyathullah, 2008). The rate of return is based on the rate of gross profit before distribution for investments of one year of the receiving bank, while the profit-sharing ratio is negotiable.

Normally, the Islamic bank investing in another bank would not at the time of negotiating the investment with the bank knows what is going to be the return until at the end of the investment period. The principal amount invested shall be repaid at the end of the investment period together with a share of the profit derived from the usage of the investment funds by the receiving bank. An equivalent of Mudarabah inter-bank investment instrument is the conventional certificates of deposit. These securities are purchased by Islamic banks so as to earn a return as well as ensure adequate liquidity. In a nutshell, Mudarabah inter-bank investment securities are issued by Islamic banks whenever there is a temporary deficit of fund. The decision by Islamic inter-bank market to use Mudarabah concept and naming the instrument Mudarabah inter-bank investment is premised around the fact that Islam based on Shari'ah principles of Islamic finance prohibits lending and borrowing on interest but allows profit-sharing model. The process of the Mudarabah inter-bank investment is diagrammatically depicted in figure 2: 
Figure 2 The Process of Mudarabah Interbank Investment

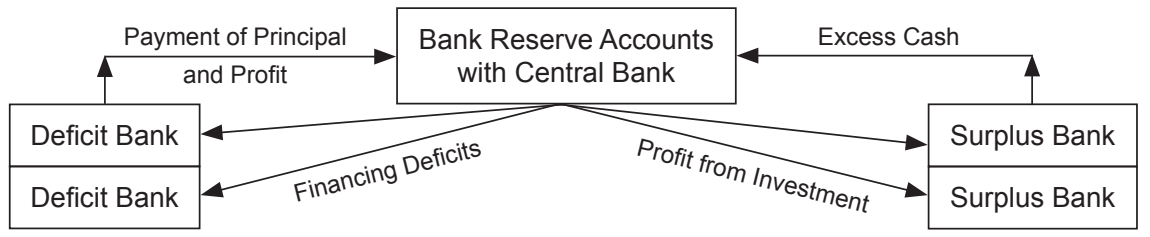

Source: Nuradli Ridzwan (n.d)

At the inception of Islamic banks in Malaysia, there was an urgent and serious need for them to hold liquid securities in order to be able to meet their statutory liquidity requirements and to mop up their idle funds. This seemed a herculean task because going by Shari'ah rules that frown on riba, Islamic bank then were unable to purchase or trade in the available Malaysian government securities, Malaysian treasury bills and other interest bearing instruments. Succour was later provided in 1983 by the enactment of the government investment Act which allowed the issuance of non-interest bearing certificates known as Government Investment Certificates (GIC) based on qard hasan concept with maturities of one year or more and for dividend instead of interest (Hakim, 2007).

However, trading government investment certificates in the secondary market is not permitted under qard hasan. Therefore, a window was opened by the central bank to make the sale and purchase of the securities by market participants more effective. The central bank sets the prices of securities which maintain a system that keeps track of the changes in the government investment certificates (GIC). The relationship between the holder of a GIC and the issuer is usually based on a restricted Murabahah contract. However, according to IFSB (2008) "The instrument's maturity profile ranges from two to six years. The expected return is determined by the fixed rental income on Ijarah plus the incomes from the sale of Murabahah, Salam and Istisna' contracts and profit is distributed every three or six months".

\section{Islamic Accepted Bills (IAB)}

An order given by a bank to a bank customer to pay on its behalf a sum of money at a future date is known as Islamic Accepted Bill (also known as interest free accepted bill). Endorsement of the order for future payment by the customer bank automatically makes it responsible for the ultimate payment to the holders of the acceptances. This Islamic Accepted Bill facility can be used for two types of financing namely; import or purchase and export or sales of only halal commodities. Islamic Accepted Bill was purposely introduced to encourage 
and promote both international and local trade as well as cross-border liquidity movement. The bill operates on the basis of both Islamic principles; Murabahah (i.e. deferred lump sum sale or cost-plus) and Bai dayn (Sale of debt).

\section{Wadi'ah Inter-bank Acceptance}

Wadi'ah acceptance is a financial certificate which represents the transaction between Islamic banks and the Central Bank. This is an instrument through which the surplus funds of Islamic banking institutions are placed in the custody of the Central bank based on the concept of Wadi'ah. The custodian of these funds is not under any obligation to pay a specific return but at its own discretion the custodian can pay dividend to the owner of funds in the form of hibah (gift). Because Wadi'ah Acceptance allows Central Bank flexibility in declaring dividend without compulsion to invest the funds in its custody, it facilitates liquidity management operation of Central Bank. Under this operation which involves acceptance of overnight money or fixed tenure Wadi'ah, Central Bank uses Wadi'ah Acceptance to mop up excess liquidity in the Islamic Inter-bank money market.

\section{Islamic Negotiable Instruments (INI)}

There are two forms of this financial instrument. The first one is the form known as Islamic Negotiable Instruments of Deposit (INID). This instrument refers to depositing a sum of money with Islamic banks and repayable to the bearer on an agreed future date at the nominal value of the instrument plus dividend declared by the Islamic banks. The INID operates based on Mudarabah concept. The second form is Negotiable Islamic Debt Certificates (NIDC) which involves the sale of banking institution's assets to a customer at an agreed price on cash basis. The bank subsequently purchase the assets back from the buyer (customer) at the principal value plus profit which is to be settled at an agreed future date.

\section{Al-Rahnu Agreement}

This instrument is structured and operates based on the concept of qard hasan whereby a lender provides a loan to a borrower who pledges certain securities as collateral against the loan. In case there is default on the part of the borrower by failing to pay the loan upon maturity, the lender is authorised to sell the pledged securities and use the proceeds to settle the loan. In a situation where surplus is recorded on the money, the lender is expected to return the balance to the borrower. Central Bank uses this structure as a liquidity management tool for money market operations. Returns generated from this instrument are considered as gift (hiba) and are determined according to the average inter-bank money market rates. 


\section{Islamic Private Debt Securities (IPDS)}

Though the securities had been in existence since 1990 but currently they are being issued in the market under several Shari'ah based concepts such as Baibithaman ajil, Qard hasan, Murabahah, and Mudarabah. Under the Bai-bithaman ajil concept the financial institution purchases an asset from the borrower and later resells the asset at a higher price. This price is made up of the cost and the profit elements. The loan arising from the finance is securitised via the issuance of two notes, i.e. the primary and secondary notes. The primary note is equivalent to the price of the purchased asset from the borrower by the financier while the secondary note is equivalent to the value of the profit realised from the resold asset (Billah, n.d). These notes are traded in the secondary markets on the basis of Bai dayn concept.

The Qard hasan is an interest free loan given either for welfare purpose or for addressing short-term funding requirements. The issued notes confirm the debt for the amount which is to be repaid at a future date. The loan is to be repaid through the liquidation of Islamic Debt Securities after an agreed certain period of time. Several studies consider Islamic Debt Securities as an alternative to the issuance of the conventional zero coupon bonds.

\section{Repurchase Agreement}

The conceptual framework of this transaction is quite similar to the conventional approach, but the applications are not exactly the same. Conventional repo is an agreement between a buyer and a seller whereby the seller of securities undertakes to sell securities and subsequently buy back the securities from a buyer at an agreed higher price on a specified future date. However, in order to replicate the bilateral conventional repo, two distinct contracts need to be involved in Islamic repo.

The first contract entails the deficit unit selling Shari'ah compliant securities to the surplus unit (buyer) in return for cash payment, and thereby funding its liquidity shortfalls (Mark, 2011). This transaction also involves transferring of title of ownership to the surplus unit, and thus, the surplus unit is not compelled to sell the securities back to the seller (borrower). Taking place simultaneously is the deficit unit (seller) giving an undertaking ( $w a^{\prime} a d$ ) to the surplus unit (lender) under which it would be agreed to buy back the original securities from the lender on a specified date for a fixed price. The second contract takes place at the maturity of the transaction and involves the surplus unit selling back to the deficit unit the same original securities in return for a sale price amounting to cost plus mark-up. However, Mark (2011) stressed that a Shari'ah-compliant repo would definitely be a breakthrough for the Islamic money market as it would provide Islamic financial institutions access to a tradable money market instruments and would also be of advantage for the secondary market in Sukuk. 


\section{Islamic Money Market and Liquidity Risk Management}

Islamic banks, like their conventional counterparts have to meet their liquidity needs and obligations to ensure smooth running of the business as well as proper functioning of the overall banking system. Moreover, the unique nature of Islamic banks with the prohibition of any form of riba (interest) is an additional issue to be addressed in order to meet their liquidity needs and assuage liquidity risk via a Shari'ah compliant approach. Addressing these issues necessitated introduction and establishment of Islamic interbank money markets. However, attempts by central banks to develop Islamic Interbank money markets that could aid liquidity management of Islamic banks and other financial institutions have up to date recorded limited success. This according to studies can be attributed to inadequate availability of suitable Shari'ah compliant instruments and the weaknesses of the required supporting infrastructures for active Islamic money markets.

Meanwhile in an attempt to assuage these problems Abdul Majid (2003) suggested three alternatives to the conventional inter-bank markets that if it can be considered, may assist in providing short-term liquidity to Islamic banks when the need arises. The suggested alternatives are the followings:

- Islamic Banks could have an agreement with other banks for mutual financing facilities as practiced by conventional banks, but such should be within the framework of profit-loss sharing. Banks which are in need of more resources from others may enter into mutual agreement of profit and loss sharing arrangement. This will enable them to place surplus funds, arrange liquidity when the need arises and balance their short-term assets and liabilities.

- The second suggestion involves an inter-bank cooperative arrangement to extend reciprocal accommodation to each other on condition that the net use of this facility is zero over a given period.

- And the third one is that the banks could create a common pool at the central bank to provide mutual accommodation.

\section{Conclusion and Recommendations}

The major concern of Islamic banking institutions is in having interest-free liquidity management, where a vibrant and efficient Islamic money market plays an important role towards achieving this feat. Islamic money market (otherwise known as IIMM) plays several pivotal roles in ensuring stability of Islamic finance and banking system, but liquidity management is said to be the most important. The big challenge facing the Islamic banking industry is in having 
a well-functioning and vibrant IIMMs that would enable them to manage their liquidity and liquidity risk in case of any liquidity shortfall in Shari'ah-compliant ways. However, vibrancy of IMM depends on adequate availability of varieties of Shari'ah-compliant financial instruments.

\section{Recommendations}

- Presently, it is common knowledge that some of the IIMM instruments still require improvement. Due to the rapidity in the growth of Islamic banking industry, greater efforts should be made to introduce or innovate new instruments'

- Efforts should also be made to enhance the quality and effectiveness of the present IIMM instruments, as almost all the currently available Islamic financial instruments in IIMM are either long-term or fixed in nature and thereby creates risk of funding mismatches.

- Islamic banks are presently vulnerable to liquidity risk because they engage in financing medium and long-term projects using short-term deposits. It is recommended that special and urgent attention should be paid towards developing Islamic money market instruments that would be Shari'ah compliant and at the same time facilitate meeting the liquidity requirements as well as preventing Islamic banking institutions from liquidity problem vulnerability. An initiative towards achieving this feat was the establishment of International Islamic Liquidity Management Corporation (IILM). ${ }^{1}$

- There should be greater standardisation of fatwas on the Shari'ah compliance of some Islamic money market instruments and remove the existing controversies surrounding them. This is yet another serious issue that requires urgent attention. Different Islamic countries had tried to develop short-term Islamic money market instruments under various concepts. But the problem here lies in the fact that some instruments accepted as Shari'ah compliant in one Islamic country may be rejected in some other countries especially those securities that are issued under Bai' inah and repurchase agreements (repos). This development hinders cooperation among Islamic banks especially, those operating in different jurisdictions. It also has negative impact on the crossborder transactions and liquidity management.

To conclude, all the above recommendations call for serious research, especially in the Shari'ah aspects of instruments and innovations in order to facilitate management of liquidity gap in Islamic banks and make them competitive with their counterpart conventional banks. 


\section{Notes}

* Sekoni Abiola Muttalib currently a Ph.D research candidate of Islamic Banking and Finance at IIUM Institute of Islamic Banking and Finance Malaysia (IIiBF) with multi-discipline educational background which includes; engineering, Management, Business Administration and Islamic Banking and Finance. His academic qualifications are B.ENG, M.ENG, PGDM, MBA and CIFP.

1. The role of IILM is to issue high quality Shari' ah-compliant financial instruments at both the national level and across borders, in an integrated manner in order enhance the soundness and stability of financial system in any jurisdictions in which they operate. Zulkifli (2010) asserts that the primary objective of the IILM is to issue Shari'ah-compliant financial instruments so as to facilitate more effective and efficient liquidity management solutions for financial institutions offering Islamic financial services, as well as to facilitate greater investment flows of Shari'ah-compliant instruments across-borders. The establishment of IILM is considered a breakthrough in the global development of Islamic financial industry, as it is expected to perform pivotal role in facilitating cross-border Islamic liquidity management.

\section{References}

Abdul Majid A. R. (2003). Development of Liquidity Management Institutions: Challenges and Opportunities. A paper presented at International Conference on Islamic Banking: Risk Management, Regulation and Supervision. JakartaIndonesia, 30 September - 3 October 2003.

Obiyathulla, B. I. (2008). The Islamic Inter-bank Money Market and a Dual Banking System: The Malaysian Experience. MPRA Paper No. 12699. Retrieved from http://mpra.ub.uni-muenchen.de/12699/

Bank Negara Malaysia (2011). Islamic Interbank Money Market. Retrieved from http://iimm.bnm.gov.my/index.php?ch=4\&pg=4\&ac $=22$

IFSB (2008). Technical Note on Issues Strengthening Liquidity Management of Institutions Offering Islamic Financial Services: Development of Islamic Money Markets. March 2008.

Ijlal, A. A. (2009). Interbank Money Market Operation: developing Shariah compliant Solutions, Potential for Islamic Liquidity Management. Paper presented at AAOIFI - World Bank Annual Conference on Islamic Banking and Finance. 1415 December 2009. Kingdom of Bahrain.

KFH (2012). Malaysian Islamic Money Markets. Islamic Finance Research, February 2012.

Mark, M. (2011). "The Islamic Money Market and its Relevance to the Islamic Capital Markets" in Rahail Ali (ed.). Sukuk and Islamic Capital Markets: A Practical Guide, London: Global Business Publishing Ltd.

Billah, M. M. (n.d). Concepts of Islamic Money Market. Retrieved from www. applied-islamicfinance.com/sp_money_market_1.htm

Nik Maheran, N. M. (n.d). Money Market. Study Guide for Malaysian Financial Market and Institution. 
Nuradli, R. S. M. (n.d). Instruments in Islamic Money Market in Malaysia. Retrieved from www.kantakji.com/fiqh/Files/Economics/174.doc

Rahail, A. (2011). An Overview of the Sukuk Market. In Rahail Ali (ed.). Sukuk and Islamic Capital Markets: A Practical Guide. London: Global Business Publishing Ltd.

Robert, R. and Lotte, S. Z. (2009). Financial Crisis and Money Markets in Emerging Asia. Asian Development Banks, ADB Working Paper Series on Regional Economic Integration. No. 38, November 2009.

Hakim, S. R. (2007). "Islamic Money Market Instruments" in M. Kabir Hassan and Mervyn, K. Lewis (ed.). Handbook of Islamic Banking. Edward Elgar: Cheltenham.

Sundararajan, V. and Errico, L. (2002). Islamic Financial Institutions and Products in the Global Financial System: Key Issues in Risk Management and Challenges Ahead, IMF Working Paper 02/192. Retrieved from www.imf.org/external/pubs/ $\mathrm{ft} / \mathrm{wp} / 2002 / \mathrm{wp} 02192 . \mathrm{pdf}$

Timothy, Q. C. and Robert, K. L. (1998). Instruments of the Money Markets. Federal Reserve Bank of Richmond, Richmond, Virginia.

Zulkifli, H. (2010). Establishment of International Islamic Liquidity Management Corporation (IILM) is a Big Relief. Retrieved from http://arabnews.com/economy/ islamicfinance/article158430.ece 